\title{
Introducing the newly developed SB Knife Jr 2: enhancing creative endoscopic submucosal dissection
}

Endoscopic submucosal dissection (ESD) using a scissor-type knife has notable benefits [1 - 5]. Its design and rotatability allow increased stability and accurate control of dissection. Additionally, it is useful for accurate vessel sealing and hemostasis. The SB Knife Jr (Sumitomo Bakelite, Tokyo, Japan), developed in 2011, is available worldwide [1]. However, there are some issues related to its use, such as poor repetitive incisional performance, interference with the hood, and cumbersome operation by the assistant. The latest version, the SB Knife Jr 2 (Sumitomo Bakelite), is, like the conventional model, a fully rotatable scissor-type knife with insulated sides to avoid muscular injury, but it also has features addressing the above-mentioned issues, thereby enhancing the safety of ESD. New features of the SB Knife Jr 2 relate to (1) the knife structure, to improve the ability to grasp tissue; (2) the scissor structure, to avoid interference with the hood; (3) the coating of the knife, to improve the repetitive incision ability; and (4) the new rotation operation part ( $\mathbf{F i g . 1}$ ). We demonstrate two ESD procedures using the SB Knife Jr 2 ( $\vee$ Video 1 ).

The first case was a flat tumor $(10 \times$ $15 \mathrm{~mm}$ ) in the greater curvature of the gastric remnant ( $\mathbf{F i g . 2}$ a, Fig. 2 b). We started ESD using a tip-type knife (Dual knife; Olympus, Tokyo, Japan); however, massive bleeding occurred, and endoscopic maneuverability was poor. As the dual knife was seen positioned vertically to the muscle layer, we switched to an SB Knife Jr 2, which allowed an approach parallel to the muscle layer. In addition, vessels were successful-

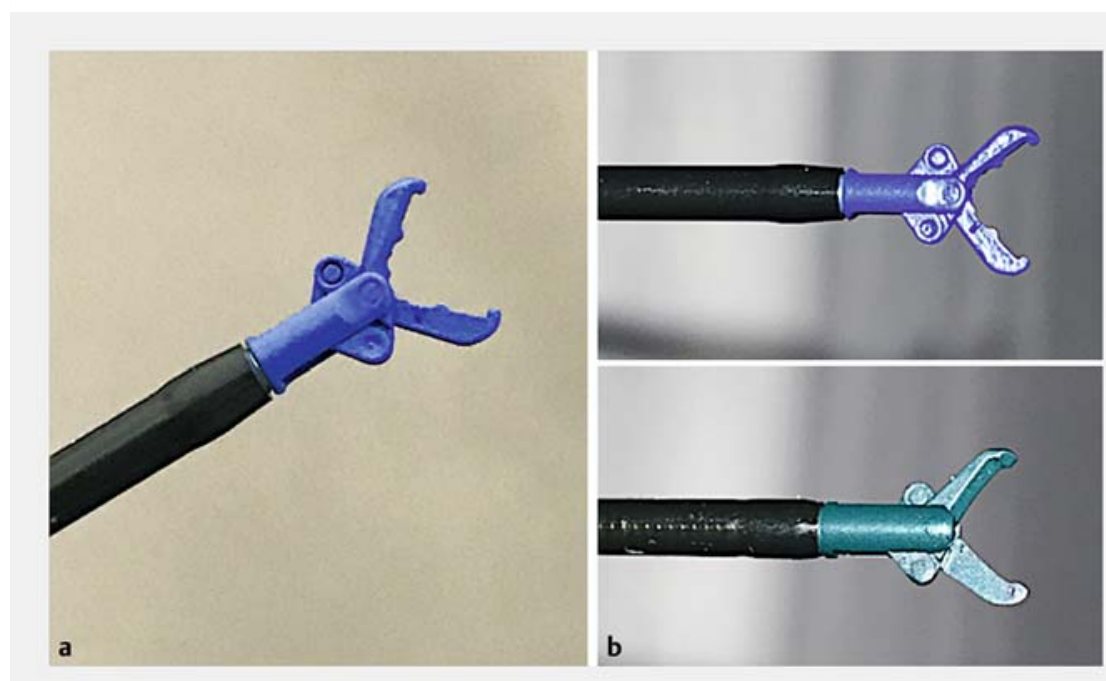

- Fig. 1 a The newly developed SB knife Jr 2. b Comparison of conventional SB knife Jr (above) and the later SB knife Jr 2 (below). The two models are similar in size, with $3.5 \mathrm{~mm}$ length and $4.5 \mathrm{~mm}$ opening. The SB knife Jr 2 has increased the grasping ability of its knife part, and its slim structure reduces interference with the hood and working channel.

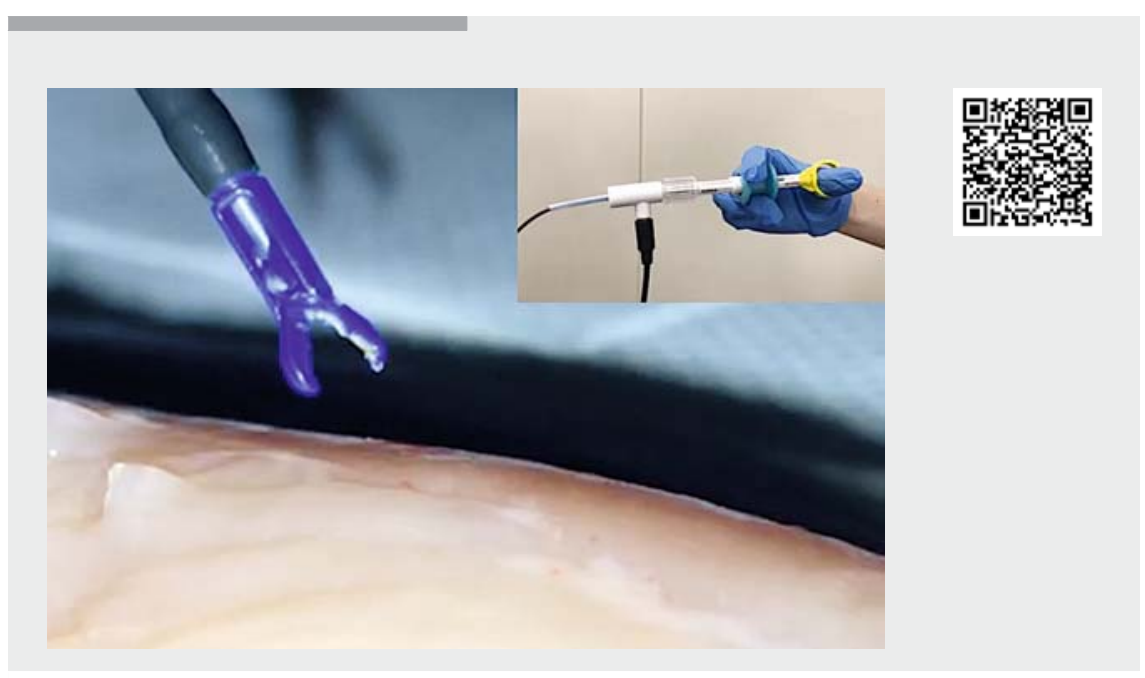

$\checkmark$ Video 1 Endoscopic submucosal dissection using an SB Knife Jr 2 to treat neoplasms in the gastric remnant and duodenum. 


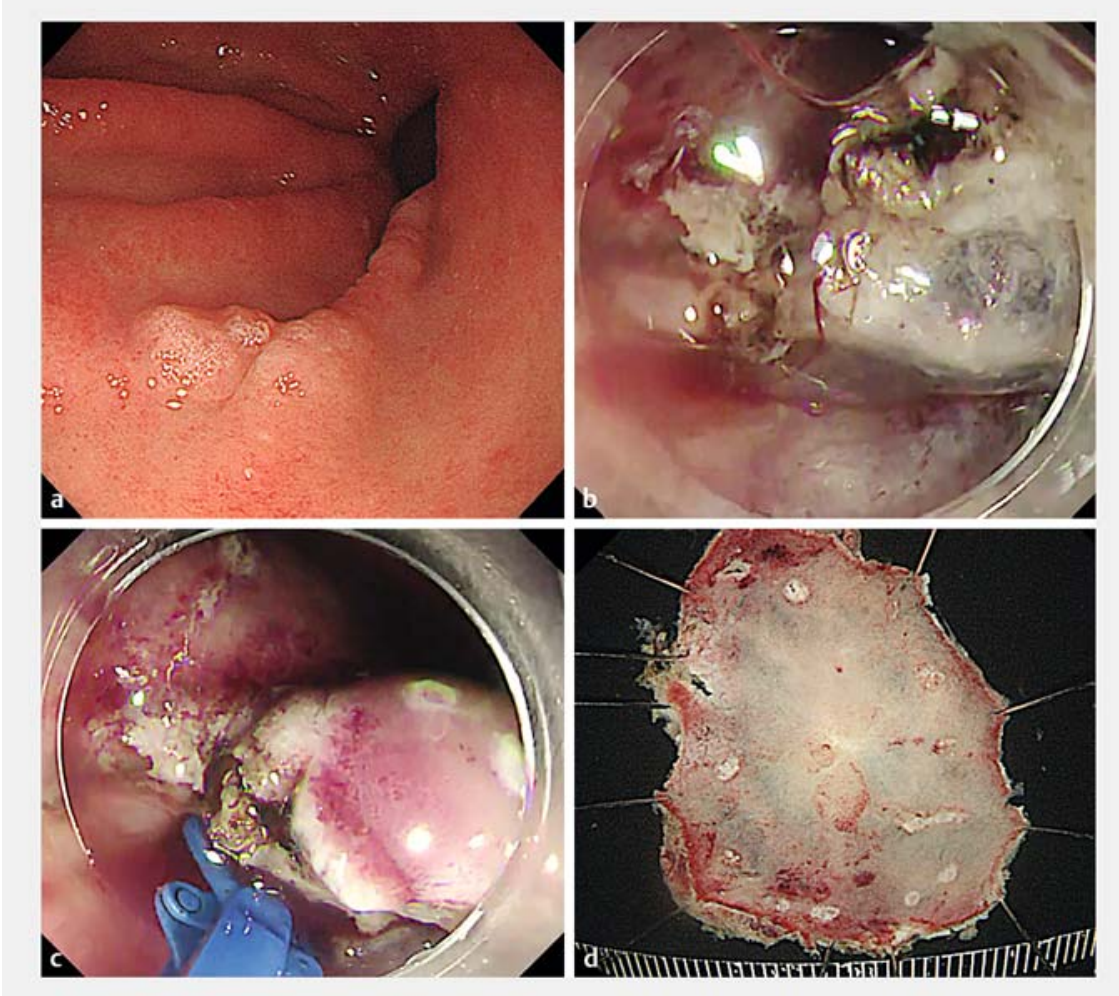

Fig. 2 a A flat lesion, $10 \times 15 \mathrm{~mm}$ in diameter, located in the greater curvature of the gastric remnant. $\mathbf{b}$ In addition to originally poor endoscopic maneuverability, well developed vessels were present. c To prevent further bleeding, we switched from the Dual knife to the SB knife Jr 2 . The submucosal dissection was performed in the parallel direction just above the muscle layer. $\mathbf{d}$ Resected specimen. Pathological examination revealed a high-grade adenoma with negative horizontal and vertical margins.

ly sealed by grasping, thereby decreasing the chances of bleeding ( $\vee$ Fig. 2 c, $>$ Fig. 2d).

The second case was a $40 \times 35-\mathrm{mm}$ pedunculated duodenal tumor ( $\triangleright$ Fig. 3 a,

- Fig. $\mathbf{3 b}$, $>$ Fig. $\mathbf{3 c}$ ). The stalk of the tumor was short, and its head was wide. Endoscopic maneuverability was poor because of the duodenal anatomy. Here, ESD using an SB Knife Jr 2 was performed to avoid incomplete resection ( Fig. $3 \mathrm{~d}$ ).
The authors declare that they have no conflict of interest.
The authors

Yasutoshi Shiratori, Takashi Ikeya, Katsuyuki Fukuda

Division of Gastroenterology, St. Luke's

International Hospital, Tokyo, Japan

Corresponding author

\section{Yasutoshi Shiratori, MD}

9-1 Akashi-cho, Chuo-ku, 104-8340 Tokyo, Japan

Fax: +81-3-3541-5151

shiraya@luke.ac.jp

\section{References}

[1] Ge PS, Thompson CC, Aihara H. Endoscopic submucosal dissection of a large cecal polyp using a scissor-type knife: implications for training in ESD. VideoGIE 2018; 3: 313-315

[2] Tamaru Y, Kuwai T, Ishaq S. Endoscopic submucosal dissection of colorectal tumors using a novel monopolar scissor-type knife “SB Knife Jr. 2". Dig Endosc 2019; 31: e105e106

[3] Dohi O, Yoshida N, Naito Y et al. Efficacy and safety of endoscopic submucosal dissection using a scissors-type knife with prophylactic over-the-scope clip closure for superficial non-ampullary duodenal epithelial tumors. Dig Endosc 2019. doi:10.1111/den.13618

[4] Tashima T, Nonaka K, Ryozawa S et al. Duodenal endoscopic submucosal dissection for a large protruded lesion located just behind the pyloric ring with a scissor-type knife. VideoGIE 2019; 4: 447-450

[5] Miyakawa A, Kuwai T, Sakuma Y et al. Learning curve for endoscopic submucosal dissection of early colorectal neoplasms with a monopolar scissor-type knife: use of the cumulative sum method. Scand J Gastroenterol 2020: 1-9. doi:10.1080/ 00365521.2020 .1807597 

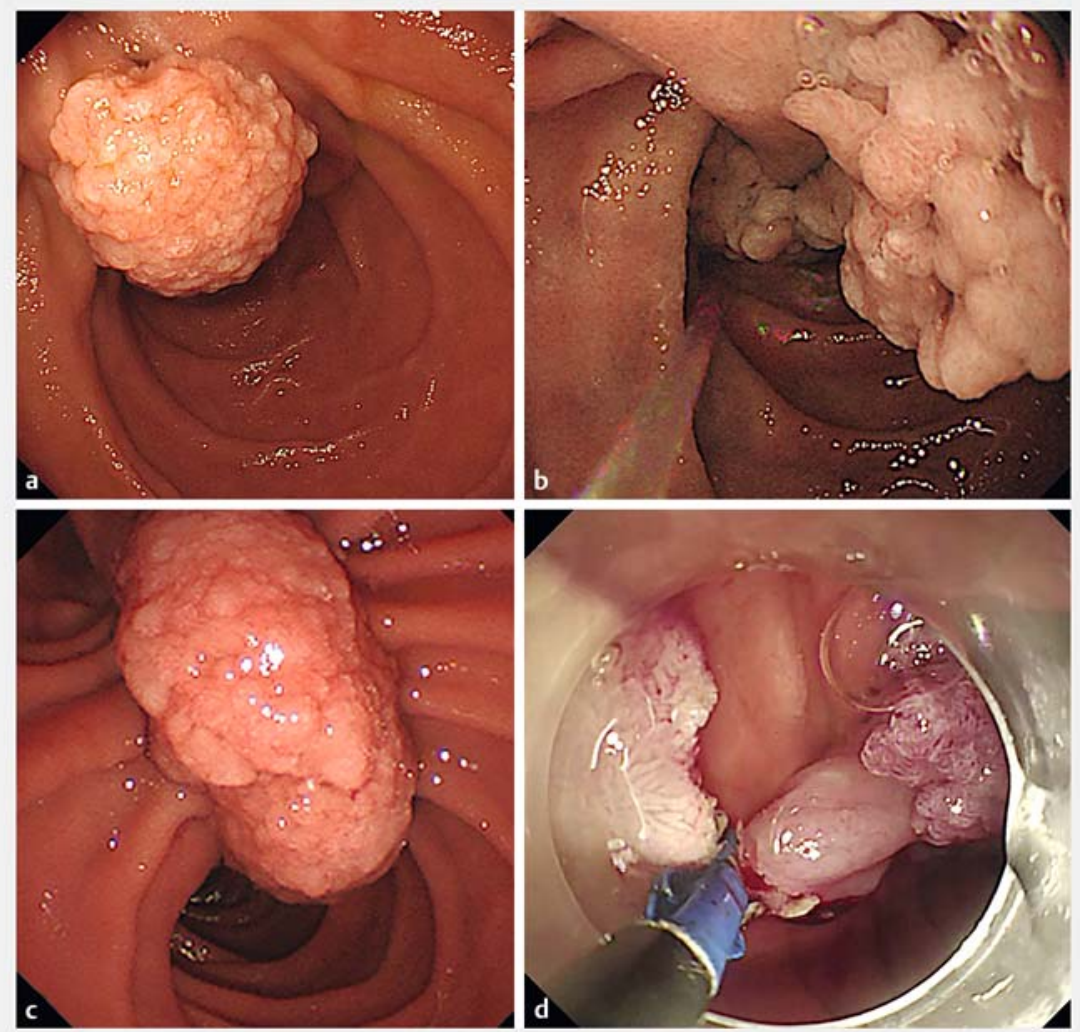

\section{Bibliography}

Endoscopy 2021; 53: E352-E354

DOI 10.1055/a-1292-4426

ISSN 0013-726X

published online 19.11.2020

(c) 2020. Thieme. All rights reserved.

Georg Thieme Verlag KG, Rüdigerstraße 14,

70469 Stuttgart, Germany

\section{ENDOSCOPY E-VIDEOS \\ https://eref.thieme.de/e-videos}

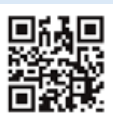

Endoscopy E-Videos is a free access online section, reporting on interesting cases and new

techniques in gastroenterological endoscopy. All papers include a high quality video and all contributions are freely accessible online.

This section has its own submission website at https://mc.manuscriptcentral.com/e-videos

- Fig. 3 a Conventional endoscopic image of a $40-\mathrm{mm}$ pedunculated lesion in the descending duodenum. $\mathbf{b}$ The head of the tumor was large, and the stalk was short. The anal side of the tumor was not evaluated by forward-viewing endoscopy. In addition, because the lesion was located just above the inferior duodenal angle, endoscopic maneuverability was poor. c Duodenoscopy revealed that the anal side of the tumor exceeded the inferior duodenal angle. $\mathbf{d}$ Endoscopic dissection of the submucosal layer was performed using an SB knife Jr 2. The procedure was done by backward and forward movement of the knife without any interference with the hood. En bloc resection was achieved without causing any adverse events such as severe bleeding and perforation. 